\title{
Elektroniczne wydawanie zbiorów korespondencji - dokonania i perspektywy
}

\author{
Joanna Haeaczkiewicz \\ (Uniwersytet Jagielloński, Kraków)
}

W ostatnich latach w rodzimym środowisku edytorskim można zaobserwować wzrastające zainteresowanie teorią i praktyką przygotowania naukowych edycji elektronicznych (scholarly digital editions). Nie da się ukryć sporego opóźnienia w stosunku do podobnych działań podejmowanych za granicą, cieszy jednak, że obok entuzjastycznych głosów na temat możliwości wykorzystania nowinek technologicznych coraz częściej pojawiają się wypowiedzi-sprawozdania z prac nad konkretnymi polskimi edycjami ${ }^{1}$. Przegląd dotychczas zrealizowanych na świecie przedsięwzięć dowodzi, że szczególnie często na warsztat edytorów elektronicznych trafiają teksty, których kompozycja odbiega od linearności znanej z tradycyjnych powieści ${ }^{2}$ - obszernych, pisanych prozą, dzielonych na tomy i rozdziały. Znacznie chętniej przenosi się do świata cyfrowego teksty utworów (szeroko rozumianych) o skomplikowanej budowie, a zatem w tej formie wydaje się różnego rodzaju szkice i dokumentacje, całe archiwa, dokumenty osobiste: diariusze, pamiętniki, notatniki, wreszcie - zbiory korespondencji3 ${ }^{3}$ Ta ten-

1 Zob. np. A. Skolimowska, Prace nad niemieckojezzycznq częścią korespondencji Jana Dantyszka-perspektywy internetowej publikacji tekstów niemieckich Dantyszka, w: Reformacja w dawnej Rzeczypospolitej i jej europejskie konteksty. Postulaty badawcze, red. P. Wilczek, Warszawa 2014, s. 120-125 (Reformacja w Polsce i Europie Środkowo-Wschodniej, 1); A. Skolimowska, M. Turska, XML Scriptorium. The $X M L$ editor as a tool for publishers of modern sources, on the example of the "Corpus of Ioannes Dantiscus' Texts and Correspondence", http://fontes.al.uw.edu.p1/html/XMLScriptorium.pdf (stan z 3 czerwca 2017 r.); A. Kochańska, K. Niciński, Cyfrowa edycja listów Lechonia, Wierzyńskiego i Grydzerwskiego - zatożenia projektu $i$ wstępne rozpoznania, „Sztuka Edycji” 2016, nr 2, s. 15-20; M.B. Majewska, Prezentacja prototypowej internetowej edycji „Stownika wileńskiego", w: Nowe perspektywy w nauczaniu jezyka polskiego jako obcego, red. K. Birecka, K. Taczyńska, Toruń 2010, s. 117-126.

2 M. Pisarski, Linearność i nielinearnośc, „Techsty. Literatura i Nowe Media”, http://techsty.art.pl/hipertekst/teoria/linearnosc.htm (stan z 3 czerwca 2017 r.).

3 Zob. listę edycji elektronicznych aktualizowaną przez Patricka Sahlego: idem, A Catalog of Digital Scholarly Editions, http://www.digitale-edition.de/index.html (stan z 3 czerwca 2017 r.). 
dencja widoczna jest również w polskich, niestety wciąż jeszcze nielicznych, edycjach ${ }^{4}$.

Wymienione wyżej typy utworów strukturalnie bardzo przypominają hipertekst, który poprzez swoją niesekwencyjność oferuje czytelnikowi różne strategie lektury ${ }^{5}$, przede wszystkim zaś nie zmusza do czytania od deski do deski. Pod tym względem interesująco wygląda sprawa wydawania korespondencji. Jej status jest dwojaki: wprawdzie tworzy ona spójny ciąg myśli dwojga lub więcej osób, formalnie jednak składa się z wielu rozproszonych cegiełek - nie zawsze kompletnych, ale mimo to dających się czytać wyrywkowo. Edytor, przygotowując tradycyjną, drukowaną edycję listów, musi zdecydować, jaką kompozycję przedstawi czytelnikowi. Boryka się przy tym $z$ wieloma problemami: niepewnej datacji, zaginionych listów, wątpliwego autorstwa, braku czytelności. Często też wysyłane latami wiadomości urastają do olbrzymiego zbioru, który w połączeniu z komentarzem objaśniającym kontekst owocuje monumentalnym, wielotomowym, a przy tym zupełnie niefunkcjonalnym i bardzo drogim wydaniem. Jakakolwiek późniejsza chęć wprowadzenia poprawek, których przecież nie da się uniknąć, okazuje się kosztowna. Nie dziwi więc, że perspektywa publikowania korespondencji w edytowalnej, niezwykle pojemnej i relatywnie taniej formie elektronicznej jest coraz bardziej kusząca.

W prezentowanym artykule, posługując się przykładami istniejących edycji elektronicznych korespondencji, omówię możliwości wykorzystania medium Internetu do wydawania listów. Spojrzeniu na to, co już w edytorstwie jest, towarzyszyć będzie refleksja nad tym, co dopiero nadejdzie. Na początek jednak zostaną omówione najważniejsze cechy naukowej e-edycji. Jest to konieczne, ponieważ przez lata w kraju narosły mylne przekonania na temat jej kształtu ${ }^{6}$.

4 W chwili pisania artykułu autorce znane są jedynie dwa zrealizowane w Polsce przedsięwzięcia: edycja Stownika wileńskiego oraz Corpus of Ioannes Dantiscus' Texts \& Correspondence. Wiele natomiast mówi się o planowanych lub obecnie realizowanych projektach (nie wszystkie prowadzą do stworzenia naukowej edycji elektronicznej). Zob. Humanistyczne projekty cyfrowe w Polsce, oprac. M. Werla, M. Maryl, wer. 1.1 (26 czerwca 2014 r.), Poznań-Warszawa 2014.

5 M. Pisarski, Hipertekst - definicje, „Techsty. Literatura i Nowe Media”, http://www.techsty.art.p1/ hipertekst/definicje.htm (stan z 3 czerwca 2017 r.).

6 Wątpliwości dotyczą przede wszystkim utożsamiania edycji elektronicznych ze skanami książek gromadzonymi w bibliotekach cyfrowych, e-bookami, plikami PDF zamieszczonymi w Internecie oraz hipertekstowymi eksperymentami, jak na przykład Patuba Irzykowskiego w wydaniu Ha!artu. Wykorzystując koncepcję remediacji autorstwa Jaya Davida Boltera i Richarda Grusina, bardzo dobrze, przynajmniej w podstawowym rozumieniu, granice edycji elektronicznej wyznacza Maciej Maryl, zob. idem, Reprint i hipermedialnośc - dwa kierunki rozwoju literatury cyfrowej, w: Tekst (w) sieci, t. 2: Literatura, spoteczeñstwo, komunikacja, red. A. Gumkowska, Warszawa 2009, s. 83-91. 


\section{NAUKOWA EDYCJA ELEKTRONICZNA W ŚWIETLE PRAKTYKI}

Naukowa edycja elektroniczna to cyfrowa forma podania tekstu swobodnie wykorzystująca możliwości oferowane przez medium, jakim jest Internet. Jej podstawową cechą jest niemożność istnienia poza swoim medium: edycji elektronicznej nie da się przenieść bezstratnie na papier ani nawet na komputer pozbawiony dostępu do Internetu7 ${ }^{7}$ Adresatem takiej edycji, ze względu na skomplikowaną, bardzo zaawansowaną formę podania tekstu, jest przede wszystkim środowisko naukowców ${ }^{8}$.

Historia tworzenia edycji elektronicznych sięga początków lat dziewięćdziesiątych, kiedy to jeszcze płyta CD była podstawowym nośnikiem danych. Pierwsze edycje publikowano nie w Internecie, lecz właśnie na płytach kompaktowych, co bardziej upodabniało je do programów komputerowych niż do e-edycji w dzisiejszym rozumieniu (np. The Canterbury Tales Project- edycja Opowieści kanterberyjskich w opracowaniu Petera Robinsona z 1996 r.). Dopiero wraz z upowszechnieniem Internetu e-edytorstwo przeniosło się do sieci, w której też szybko ukonstytuowała się międzynarodowa społeczność entuzjastów nowej metody wydawania. Globalny zasięg i możliwość kooperacji od początku były powodem do dumy. Oto bowiem zmienił się model uprawiania edytorstwa: często samotnicze, nierzadko wieloletnie wysiłki filologa wyparła efektywna praca zespołowa, często wspierana systemem grantowym promującym współpracę różnych ośrodków. Dziś inspiratorzy edycji elektronicznych wychodzą jeszcze dalej i skłaniają się ku crowdsourcingowi - modelowi opierającemu się na współdziałaniu nie kilku, lecz tysięcy osób zainteresowanych określonym tematem. To oznacza, że niekoniecznie trzeba być utytułowanym akademikiem, by przyczyniać się do rozwoju nauki. W ten sposób od 2013 roku powstaje irlandzki projekt Letters of $19 I 6{ }^{9}$.

Aspekt niedokonany jest kolejną ważną cechą edycji elektronicznych. $\mathrm{O}$ ile druk książki zamyka proces pracy nad nią, o tyle moment publikacji w sieci jest naj-

7 Zob. P. Sahle, What is a Scholarly Digital Edition?, w: Digital Scholarly Editing: Theories and Practices, red. M.J. Driscoll, E. Pierazzo, 2016 (Digital Humanities Series, vol. 4), https://www.openbookpublishers.com/reader/483\#page/6/mode/2up, s. 26-28 (stan z 3 czerwca 2017 r.); zob. też: J.S. Gruchała, Wirtualny wydawca i użytkownik edycji elektronicznej, w: Europejski kanon literacki, red. E. Wichrowska, Warszawa 2011, s. 287.

8 Zob. M. Strzyżewski, Wspótczesne edytorstwo to ztożona catość, „Wielogłos” 2012, nr 3 (13), s. 167. Autor wyraża ciekawą opinię, że edytorstwo elektroniczne winno zagarnąć dawne krytyczne edycje typu A, na papierze zaś powinno się drukować strawne dla zwykłego czytelnika teksty nieprzytłoczone rozbudowanym aparatem krytycznym.

9 Celem przedsięwzięcia, skoncentrowanego wokół wydarzeń powstania wielkanocnego w Dublinie, jest skolekcjonowanie $\mathrm{i}$ udostępnienie $\mathrm{w}$ formie transkrypcji i reprodukcji jak największej liczby listów tematycznie związanych $\mathrm{z}$ wydarzeniami z lat 1915-1916. Zebrane w ten sposób dokumenty mają współtworzyć narodową narrację o minionych czasach. W masową akcję transkrybowania listów zaangażowało się już ponad 1300 osób. Letters of 1916. A Year in the Life, http://letters1916. maynoothuniversity.ie/ (stan z 3 czerwca 2017 r.). 
częściej tylko początkiem drogi do doskonalenia. E-edycja bardzo często zyskuje dookreślenie work-in-progress, a jej autorzy nie dość, że sami w dalszym ciągu prowadzą badania, to są również otwarci na sugestie czytelników (Patrick Sahle pisze: "the edition as a publication is a process rather than a product" ${ }^{\text {"O) }}$. Jest to zgodne z koncepcją Web 2.o., czyli Internetu zorientowanego na twórczą aktywność użytkowników. Tak funkcjonuje na przykład edycja korespondencji Jules'a Charles'a de l'Écluse'a (Carolusa Clusiusa), wybitnego flamandzkiego botanika i lekarza żyjącego w XVI i XVII wieku ${ }^{\text {II }}$. Członkowie Instytutów Huygensa (Huygens Institute for the History of the Netherland) i Scaligera nie ukrywaja wad swojego projektu: transkrypcje są niekonsekwentne (przygotowywały je różne osoby, częściowo do innych edycji), brakuje komentarza (ten odziedziczony po poprzednikach był tak niejednorodny, że postanowiono $z$ niego całkowicie zrezygnować), listy wciąż nie są odpowiednio otagowane, przez co całość na razie nie jest zbyt użyteczna. W przyszłości jednak edycja ma być ujednolicona pod względem reguł transkrypcji, powstanie też komentarz (na razie zaznaczono tylko miejsca, w których się on pojawi). Mimo wszystko wydaje się, że publikowanie tego rodzaju „niedoróbek” w Internecie, nie zaś na papierze, jak stało się to w wypadku trzynastu tomów Dzienników Marii Dąbrowskiej ${ }^{\mathrm{I2}}$, jest dużo lepszym wyjściem. Efekty prac można bowiem przedstawiać stopniowo, a wydatki z tym związane są nieporównanie mniejsze niż koszt opracowania nowej, tym razem krytycznej, edycji drukowanej.

Od początku tworzeniu tego typu edycji patronuje organizacja TEI (Text Encoding Initiative), której głównym celem jest przygotowanie języka opisu umożliwiającego cyfrową reprezentację tekstów (ang. markup language - język znaczników). Z założenia TEI ma w ten sposób wspierać rozwój humanistyki cyfrowej i umożliwiać międzynarodową wymianę doświadczeń. Stosowanie opracowanych przez organizację wytycznych kodowania ${ }^{\mathrm{I3}}$, dostępnych dla wszystkich za darmo, z czasem stało się wręcz wyróżnikiem naukowych edycji elektronicznych.

Istotą kodowania w TEI jest nadawanie poszczególnym elementom edytowanego tekstu odpowiednich znaczników (metatagów opartych na języku XML), które określają semantykę fragmentów - wyznaczają na przykład, co jest tytułem,

10 P. Sahle, What is a Scholarly Digital Edition?, op. cit., s. 29.

11 Clusius Correspondence. A Digital Edition-in-Progress, http://clusiuscorrespondence.huygens.knaw. $\mathrm{nl} /(\operatorname{stan} \mathrm{z} 3$ czerwca $2017 \mathrm{r}$.).

12 M. Dąbrowska, Dzienniki 1914-1965, t. 1-13 (bez opracowania edytorskiego), red. T. Drewnowski, Warszawa 2009.

13 TEI Consortium, TEI P5: Guidelines for Electronic Text Encoding and Interchange, red. C.M. Sperberg-Mcqueen, L. Burnard, ver. 3.1.0, 2016, http://www.tei-c.org/release/doc/tei-p5-doc/en/Guidelines.pdf ( $\operatorname{stan}$ z 3 czerwca 2017 r.). 
co nagłówkiem, nazwiskiem, adresem. Dopóki tekst nie zostanie odpowiednio otagowany, będzie dla komputera jedynie ciągiem znaków umieszczonych w paragrafach $(\langle p\rangle)$. Znaczniki stosuje się po to, by następnie przy ich wykorzystaniu móc sprawnie operować tekstem, a zatem na przykład umożliwić czytelnikowi sortowanie fragmentów według określonych filtrów (w edycji korespondencji przydatne może być grupowanie listów według nadawcy, roku, miejsca wysłania). TEI w połączeniu z HTML-em, bazami danych i językiem JavaScript (na przykład biblioteką jQuery) stwarza w zasadzie nieograniczone możliwości reprezentacji tekstu - barierą jest tylko wyobraźnia edytora. W wydaniach korespondencji można na przykład umożliwić wybór układu (chronologiczny od najstarszego lub najnowszego, według autora czy tematu) i sposobu objaśnień (funkcja „włącz komentarz"). Czytelnik może decydować, czy chce oglądać samą transkrypcję, a może transkrypcję w połączeniu $\mathrm{z}$ wysokiej jakości skanem, na którym dodatkowo po najechaniu kursorem podświetlają się transkrybowane słowa. Równie interesujące jest wykorzystanie metod ilościowych, dzięki którym bardzo łatwo znaleźć odpowiedź na pytanie, w jakich miesiącach i latach aktywność korespondentów była najwyższa, z których miejsc wysłali najwięcej listów, kto dłużej czekał na odpowiedź, ile czasu musiało upłynąć, nim wysłany pocztą list trafił na biurko adresata. Zebrane dane można prezentować w formie interaktywnych infografik. Tą metodą, stosunkowo jednak rzadką, posłużyli się twórcy Darwin Correspondence Project ${ }^{\mathrm{I} 4}$.

Bez wątpienia opatrywanie tekstu metatagami stało się formą pracy naukowej. Edytor nie jest zwolniony z obowiązku dokładnego odczytania wydawanego tekstu. Jego cel: udostępnić czytelnikowi dzieło tak, aby ten mógł je zrozumieć, a następnie efektywnie z niego korzystać, nadal się nie zmienił. Sztuka podejmowania decyzji rozciąga się jednak na kolejne obszary. Nie wystarczy już bowiem zebrać przekazy, porównać je, wybrać podstawę edycji, przygotować transkrypcję, wprowadzić niezbędne emendacje i koniektury, a całość opatrzyć komentarzem. Trzeba jeszcze rozważyć, jakie interaktywne funkcjonalności udostępnić czytelnikowi, a wreszcie: co i dlaczego tagować. Subiektywność tych decyzji jest bezsprzeczna, dlatego standardem w edycjach elektronicznych powinno być sprawozdanie $z$ wykorzystanych metod. Tradycyjni edytorzy dokładnie zdają relację z podjętych decyzji, objaśniają trudności, wprowadzone koniektury. Edytorzy elektroniczni winni ponadto uzasadniać wykorzystywaną strukturę tagów.

14 Listy Karola Darwina zostały ujęte w oś czasu przedstawiającą wykres słupkowy. Na stronie projektu można również znaleźć mapę z zaznaczonymi miejscami, z których naukowiec pisał do swoich adresatów. Linki, rzecz jasna, przekierowują do treści listów, wydanych również w wersji papierowej. Darwin Correspondence Project, https:/www.darwinproject.ac.uk/ (stan z 3 czerwca 2017 r.). 
Byłoby to z korzyścią nie tylko dla czytelnika, ale również dla rozwijającej się praktyki e-edycji ${ }^{15}$.

\section{LIST W ŚWIECIE HIPERTEKSTU - TECHNICZNE ASPEKTY E-EDYCJI}

Od dłuższego czasu dominującym na Zachodzie paradygmatem w przygotowaniu naukowych edycji elektronicznych jest krytyka genetyczna. Trudno się dziwić tej tendencji, biorąc pod uwagę, że edycje genetyczne, skupiające się na widocznym w rękopisach procesie dochodzenia do ostatecznego tekstu, wydają się wręcz stworzone do pokazywania w Internecie (w przeciwieństwie do druku, w którym wypadają nieczytelnie ${ }^{\mathrm{I} 6}$ ). Niektórzy zwolennicy tej metody, chyba trochę na wyrost, uważają, że wcześniej praktykowane edycje elektroniczne spod znaku textual criticism były jedynie etapem $\mathrm{w}$ rozwoju e-edytorstwa ${ }^{\mathrm{I7}}$. Zbiory korespondencji nie dają aż tak dużego pola do popisu, w ich wypadku nie ma bowiem mowy o klasycznej triadzie genetyków: avant-texte, texte, après-texte. Przeważnie korespondencje nie były przeznaczone do druku i jako takie nie były też upubliczniane. $Z$ drugiej zaś strony są one zachowane w rękopisach (tudzież maszynopisach), widać na nich liczne skreślenia, poprawki, dopiski obcych osób, czyli wszystko to, co może stać się przedmiotem fascynującej edycji genetycznej i elektronicznej.

Korespondencje jako przedmioty edycji tylko z pozoru wydają się jednorodne. $\mathrm{W}$ istocie na przestrzeni wieków ta forma komunikacji ewoluowała ${ }^{\mathrm{I} 8}$. Zmieniała się nie tylko konwencja pisania listów, ale również ich fizyczna postać. Dość powiedzieć, że dawniej nie korzystano $z$ kopert, a adresy zapisywano na odwrocie ostatniej karty listu $^{19}$. Na XIX wiek przypadają narodziny form zmuszających do zwięzłości: telegramu i pocztówek. Znakiem ubiegłego stulecia są zaś radiotelegramy i aerogramy - krótkie listy zapisywane na jednej stronie niewielkiej kartki, składanej następnie w kopertę (zapisaną stroną do środka) i wysyłanej pocztą lotniczą. Forma rzecz jasna wpływała na treść. Można mówić zarówno o silnie skonwencjonalizowanych

15 Niestety, wciąż rzadko mówi się o technicznych aspektach przygotowywania edycji elektronicznych, dlatego kolejne projekty, zamiast korzystać z bogatego doświadczenia poprzedników, niepotrzebnie usiłują być nowatorskie. Zob. C. Desenclos, Early Modern Correspondence: A New Challenge for Digital Editions, w: Digital Scholarly Editing..., op. cit., s. 197, przypis 22.

16 Zob. np. drukowane wydanie-transliterację notatników Aleksandra Wata. Idem, Notatniki, transkrypcja [!] i oprac. A. Dziadek, J. Zieliński, Warszawa 2015.

17 Pisze tak na przykład Peter Robinson, zob. idem, Towards a Theory of Digital Editions, "Variants" 2013, nr 10, s. 125 i n.

18 C. Desenclos, Early Modern Correspondence..., op. cit., s. 189.

19 Ibidem. 
listach (taki charakter ma nie tylko korespondencja urzędowa, ale i prywatna na pocztówkach), jak również o małych dziełach literackich (zob. casus listów Krasińskiego będących przejawem dążenia do stworzenia romantycznej formy otwartej ${ }^{20}$ ). Jeszcze innym zjawiskiem jest dawna korespondencja podporządkowana regułom klasycznej retoryki. Projektując edycję elektroniczną, każdą z wymienionych tu skrótowo i bez specjalnego szeregowania cech należałoby traktować indywidualnie. Jest to ważne, ponieważ zbagatelizowanie któregoś charakterystycznego elementu, jak choćby specyficznej warstwy leksykalnej, może negatywnie wpłynąć na użyteczność edycji. Przykładowo: oznaczenie wyrazów polskich w zbiorze pisanym zasadniczo po łacinie (lub odwrotnie: latynizmów w polskojęzycznej korespondencji) może być interesujące nie tylko dla językoznawców, ale również dla kulturoznawców. Historyk zaś chętnie skorzysta $\mathrm{z}$ edycji wyposażonej w indeks osób i wydarzeń historycznych po to, aby poznać opinie naocznych świadków. Warto przy tym zwrócić uwagę na to, że edycja elektroniczna, jakichkolwiek tagów by używała, udostępniając czytelnikowi zaawansowaną wyszukiwarkę, odchodzi od linearności kompozycji. Prawdopodobnie nie znajdą się osoby czytające e-wydanie zgodnie z chronologią, list po liście. Naukowa edycja elektroniczna korespondencji dąży przede wszystkim do utylitarności, a w jej osiągnięciu pomóc mają znaczniki oferowane przez standard TEI.

Wśród sympatyków opensourcéowej inicjatywy TEI istnieje specjalna grupa osób szczególnie zainteresowanych wydawaniem listów - SIG (Special Interest Group): Correspondence. Jej zadaniem jest dostosowywanie ogólnie dostępnych znaczników do własnych specyficznych potrzeb. SIG: Correspondence gromadzi informacje o powstających na świecie edycjach korespondencji, służy pomocą techniczną za pośrednictwem listy mailingowej i stara się wpływać na kształt kolejnych wersji dokumentacji TEI (obecnie obowiązuje standard $\mathrm{P}_{5}$ ). Członkowie grupy wymieniają się między sobą gotowymi rozwiązaniami, dzielą doświadczeniami, udostępniają fragmenty kodu. Okazuje się bowiem, że ten sam problem można rozwiązać na wiele sposobów, odmiennie interpretując znaczniki TEI lub tworząc nowe na podstawie dokumentacji. Na uwagę zasługuje otwarta postawa zespołu przygotowującego edycję dzieł wszystkich Karola Marii Webera ${ }^{2 \mathrm{I}}$. W projekcie, którego ukończenie przewidziano na 2026 rok, dwustulecie śmierci niemieckiego kompozytora, znalazł się też pokaźny zbiór korespondencji (według szacunków z około sześciu tysięcy listów zachowała się jedna trzecia). Prace nad jego udostępnieniem nadal trwają, już teraz jednak można zaobserwować pewne ciekawe

20 A. Markuszewska, Listy literackie Zygmunta Krasińskiego - gtówne zatożenia edycji w wyborze, „Sztuka Edycji” 2014, nr 1-2, s. 45.

21 Carl Maria von Weber. Gesamtausgabe, http://weber-gesamtausgabe.de ( $\operatorname{stan}$ z 5 czerwca 2017 r.). 
rozwiązanie. Niemal na każdej podstronie serwisu, również w przypadku listów, czytelnik ma dostęp do kodu XML jako alternatywnego widoku edycji. Co więcej - może go pobrać i wykorzystać, ponieważ niemiecka edycja rozwija się na międzynarodowej licencji Creative Commons 4.o. Chcący opracowywać podobne wydania znajdą ponadto na GitHubie zbiór plików (kod źródłowy strony) zamieszczony tam przez autorów. Zespół swoje doświadczenia przekazuje dodatkowo w SIG: Correspondence.

Dobry wgląd w strukturę e-edycji listów daje także przygotowywany w Polsce pod kierownictwem Anny Skolimowskiej elektroniczny korpus tekstów i listów Jana Dantyszka. Fragment tej olbrzymiej korespondencji można poznać od strony technicznej w serwisie TAPAS Project, gdzie Magdalena Turska, współautorka projektu, udostępniła podgląd wczesnej wersji kodu ${ }^{22}$. Podstawową jednostką strukturalną jest list. Każdy ma własny, niepowtarzalny identyfikator, na przykład „IDL042I" - list Alfonso de Valdésa do Jana Dantyszka z I6 stycznia I529 r. Numeracja listów jest niezbędna do nawigacji: porządkuje zbiór, pozwala linkować, umożliwia wyszukiwanie według numeru. W edycji identyfikatorami oznacza się też osoby (Jan Dantyszek to „PPer”), miejsca (Gdańsk to „Pl24”), język (łacina to „la”). Służy to nie tylko szczegółowemu wyszukiwaniu, ale również tworzeniu prostych, powtarzających się za każdym razem objaśnień, które pojawiają się w dymkach po najechaniu kursorem myszki na słowo. W podobny sposób zebrano objaśnienia dotyczące utworów poetyckich Dantyszka - na przykład kod <reftype="poem" target=" $16 I ">$ za każdym razem odsyła do informacji o utworze poetyckim, który w bazie danych został przyporzackkowany do numeru I6r. Jest to bardzo praktyczny komentarz wielokrotnego użytku, wykorzystujący treści zgromadzone i uszeregowane w relacyjnej bazie danych.

Metryczkę listu okalają znaczniki nagłówka <teiHeader></teiHeader $>$, wewnątrz nich znajdują się informacje o nadawcy, odbiorcy, dacie, miejscu, języku. Trzon listu znajduje się natomiast $\mathrm{w}$ znacznikach $\langle$ text $\rangle\langle/$ text $\rangle$, które są pojemnikiem dla $\langle$ body $></$ body $>\mathrm{i}<$ back $></ b a c k\rangle$. W $<$ body $>$ mieści się treść wiadomości, $<$ back $>$ zawiera komentarz. Autorki tagują między innymi ${ }^{23}$ elementy kompozycji listu $(<$ div type="salutation"> - wstępne pozdrowienie), poprawki edytorskie (<corr type="lem$m a ">)$, różnice i uszkodzenia w przekazach (<gap reason="left by scribe">), miejsca nieczytelne (<unclear>). Całość po przekonwertowaniu w HTML-u wyświetla się czytelnikowi w postaci tekstu opatrzonego linkami, podświetleniami i okienkami wywoływanymi prostym zdarzeniem onmouseover.

22 TAPAS Project. Visualize, Store, and Share Your TEI, http://tapasproject.org/ (stan z 5 czerwca 2017 r.).

23 Zob. pełną listę znaczników: A. Skolimowska, M. Turska, XML Scriptorium..., op. cit. 
Korpus tekstów i korespondencji Jana Dantyszka, mimo pewnych technicznych niedociągnięć ${ }^{24}$, jest godny uwagi również dlatego, że nie podąża głównym nurtem propagowanym na Zachodzie. Autorki czerpią wyraźnie z tradycji polskiego edytorstwa, w którym obowiązuje podział na transkrypcję i transliterację (za granicą nazywaną „transkrypcją dyplomatyczną”), nie unikają modernizacji tekstu, dołączają komentarz. Ta ważna z perspektywy polskiego edytorstwa elektronicznego edycja dowodzi, że nie bez przyczyny w dokumentacji TEI - w rozdziale dwunastym znalazły się znaczniki umożliwiające tworzenie aparatu krytycznego i komentarzy. Co więcej, ich poprawne zastosowanie wydatnie podnosi użyteczność e-edycji.

Projekt warszawskiej Pracowni Edytorstwa Źródeł i Humanistyki Cyfrowej powstał przy użyciu specjalnie dla niego zaprogramowanego narzędzia, nieskomplikowanego edytora XML Scriptorium. Nie jest to uniwersalny program typu WYSIWYG (ang. what you see is what you get), jakiego oczekiwaliby na przykład twórcy zapowiadanej edycji korespondencji Lechonia, Wierzyńskiego i Grydzewskiego ${ }^{25}$. Scriptorium tak naprawdę jest swego rodzaju „ściągawką” dla początkujących użytkowników TEI-XML: opiera się na ograniczonym zbiorze znaczników wyjętych z dokumentacji TEI specjalnie na potrzeby konkretnej edycji. Szanse ponownego użycia tego programu $\mathrm{w}$ innym projekcie, choć istnieją, nie są jednak zbyt duże. Jednocześnie każdy zainteresowany kodowaniem tekstu znajdzie w sieci przeznaczone do tego celu uniwersalne i bezpłatne programy. Aby się jednak nimi efektywnie posługiwać, musi bardzo dobrze poznać język programowania. Fakt ten każe się zastanowić nad przyszłością kształcenia edytorów, być może umiejętność programowania powinna stać się czymś tak naturalnym jak czytanie i pisanie. Innego zdania są Agnieszka Kochańska i Konrad Niciński, uczestnicy grantu Skamandrycka triada na emigracji. Edycja listów Jana Lechonia, Kazimierza Wierzyńskiego i Mieczystawa Grydzewskiego (publikacja książkowa i cyfrowa). Zapowiadają oni, że w ramach projektu, planowanego na lata 2015-2020, powstanie dające się ponownie wykorzystać narzędzie do kodowania w TEI-XML oparte na interfejsie WYSIWYG. Co więcej - i to brzmi szczególnie interesująco - ma to być wtyczka zintegrowana z najpopularniejszym obecnie systemem CMS (ang. content management system), czyli platformą Wordpress ${ }^{26}$. Jeśli plany te rzeczywiście zostaną zrealizowane, naukowe edytowanie listów w Internecie może się stać niemal tak proste jak prowadzenie bloga.

24 Obnaża je zwłaszcza podgląd kodu źródłowego, w którym można znaleźć polskojęzyczne notatki, co w przypadku edycji aspirującej do miana międzynarodowej nie powinno się zdarzyć.

25 A. Kochańska, K. Niciński, Cyfrowa edycja listórw..., s. 16-17.

26 Ibidem, s. 17. Warto dodać, że w katalogu wtyczek Wordpressa znajduje się już jedna służąca kodowaniu w TEI („TEIPress”), sądząc jednak po liczbie aktywnych instalacji, nie odniosła ona sukcesu. 


\section{PodsumowANIE: PERSPEKTYWY EDYTORSTWA ELEKTRONICZNEGO LISTów}

Publikowanie listów przypominające dodawanie wpisów na blogu to tylko jedna z perspektyw rysujących się przed e-edytorstwem korespondencji i wszelkich innych prywatnych dokumentów. Integracja $z$ Wordpressem czy też innym systemem zarządzania treścią nie oznacza rzecz jasna, że edycje elektroniczne zaczną wizualnie przypominać tradycyjne blogi. Byłaby to raczej zmiana o charakterze funkcjonalnym, jeszcze bardziej uwydatniająca zjawisko work-in-progress. Należy się ponadto spodziewać, że w przyszłości reprodukcje przekazów będą prezentowane w lepszej jakości, błędy - również dzięki czujności czytelników - zostaną usunięte, a szczególny nacisk położy się na interaktywność i poprawę interfejsu. Warto dążyć do tego, by e-edycja stała się podstawowym, a nie tylko alternatywnym źródłem dla badaczy. Nie trzeba się przy tym obawiać, że publikowanie w Internecie daje asumpt do kradzieży. Prawa autorskie zakazujące swobodnego rozpowszechniania dzieła przed upływem siedemdziesięciu lat od śmierci autora nie stanowią tu żadnej przeszkody, można wszak wyobrazić sobie edycje z płatnym dostępem. Szanse nieuprawnionego kopiowania są przy tym mniejsze, ponieważ immanentną cechą edycji elektronicznej jest niemożność jej wydrukowania lub wzięcia sobie na własność.

Patrick Sahle pisze, że dziś edycja papierowa straciła wyłączność, a jej równoprawną partnerką jest edycja elektroniczna, dlatego należy odrzucić bibliocentryczne uprzedzenia ${ }^{27}$. Trudno prorokować, co się stanie ze wszystkimi typami edycji, można jednak nieśmiało przypuszczać, że w przyszłości korespondencje będą wydawane przede wszystkim w wersji elektronicznej. Za taką zmianą przemawia raczej nie powtarzane od kilkunastu lat przekonanie o śmierci papierowej książki (skądinąd mało realne), lecz proste kryterium użyteczności. Dokumenty osobiste, na przykład listy, rzadko czyta się jak dobrą prozę. Znacznie częściej sięga się po nie w określonym celu, głównie badawczym - pod tym względem zaś edycja papierowa już dawno została w tyle za swoją młodszą siostrą.

\section{Bibliografia:}

Carl Maria von Weber. Gesamtausgabe, http://weber-gesamtausgabe.de;

Clusius Correspondence. A Digital Edition-in-Progress, http://clusiuscorrespondence.huygens.knaw.nl/;

Corpus of Ioannes Dantiscus Texts E Correspondence, red. A. Skolimowska, M. Turska, K. Jasińska-Zdun, http://dantiscus.ibi.uw.edu.pl; 
Darwin Correspondence Project, https://www.darwinproject.ac.uk/;

Dąbrowska M., Dzienniki 1914-1965, t. 1-13 (bez opracowania edytorskiego), pod kierunkiem T. Drewnowskiego, Warszawa 2009;

Desenclos C., Early Modern Correspondence: A New Challenge for Digital Editions, w: Digital Scholarly Editing: Theories and Practices, red. M.J. Driscoll, E. Pierazzo, 2016 (Digital Humanities Series, vol. 4), https://www.openbookpublishers.com/reader/483\#page/6/mode/2up;

Gruchała J.S., Wirtualny wydawca i użytkownik edycji elektronicznej, w: Europejski kanon literacki, red. E. Wichrowska, Warszawa 2011;

Humanistyczne projekty cyfrowe w Polsce, oprac. M. Werla, M. Maryl, wer. 1.1 (26 czerwca 2014 r.), Poznań-Warszawa 2014.

Kochańska A., Niciński K., Cyfrowa edycja listów Lechonia, Wierzyńskiego i Grydzerwskiego - zatożenia projektu i wstepne rozpoznania, „Sztuka Edycji”2016, nr 2, s. 15-20;

Letters of 1916. A Year in the Life, http://letters1916.maynoothuniversity.ie/;

Majewska M.B., Prezentacja prototypowej internetowej edycji „Stownika wileńskiego”, w: Nowe perspektywy w nauczaniu języka polskiego jako obcego, red. K. Birecka, K. Taczyńska, Toruń 2010, s. 117-126;

Markuszewska A., Listy literackie Zygmunta Krasińskiego - gtówne zatożenia edycji w wyborze, „Sztuka Edycji” 2014, nr 1-2, s. 45-53;

Maryl M., Reprint i hipermedialnośc-dwa kierunki rozwoju literatury cyfrowej, w: Tekst (w) sieci, t. 2: Literatura, spoteczeństwo, komunikacja, red. A. Gumkowska, Warszawa 2009;

Pisarski M., Hipertekst - definicje, „Techsty. Literatura i Nowe Media”, http://www.techsty.art.pl/hipertekst/definicje.htm;

Linearnośc i nielinearnośc, „Techsty. Literatura i Nowe Media”, http://techsty.art.pl/hipertekst/teoria/linearnosc.htm;

Robinson P., Towards a Theory of Digital Editions, „Variants” 2013, nr 10, s. 105-131;

Sahle P., A Catalog of Digital Scholarly Editions, http://www.digitale-edition.de/index.html;

What Is a Scholarly Digital Edition?, w: Digital Scholarly Editing: Theories and Practices, red. M. J. Driscoll, E. Pierazzo, 2016 (Digital Humanities Series, vol. 4), https:/www.openbookpublishers.com/reader/483\#page/6/mode/2up;

Skolimowska A., Prace nad niemieckojęzycznq częściq korespondencji Jana Dantyszka - perspektywy internetowej publikacji tekstów niemieckich Dantyszka, w: Reformacja w dawnej Rzeczypospolitej i jej europejskie konteksty. Postulaty badawcze, red. P. Wilczek, Warszawa 2014, s. 120-125 (Reformacja w Polsce i Europie Srodkowo-Wschodniej, 1);

Skolimowska A., Turska M., XML Scriptorium. The XML editor as a tool for publishers of modern sources, on the example of the "Corpus of Ioannes Dantiscus' Texts and Correspondence", http://fontes.al.uw.edu.pl/html/ XMLScriptorium.pdf;

Strzyżewski M., Wspótczesne edytorstwo to ztożona catośe, „Wielogłos” 2012, nr 3 (13), s. 165-172;

TAPAS Project. Visualize, Store, and Share Your TEI, http://tapasproject.org/;

TEI Consortium, TEI P5: Guidelines for Electronic Text Encoding and Interchange, red. C.M. Sperberg-Mcqueen, L. Burnard, ver. 3.1.0, 2016, http://www.tei-c.org/release/doc/tei-p5-doc/en/Guidelines.pdf;

Wat A., Notatniki, transkrypcja i oprac. A. Dziadek, J. Zieliński, Warszawa 2015.

SŁOWA KLUcze: naukowa edycja elektroniczna, korespondencja, humanistyka cyfrowa, krytyka tekstu, TEI 


\section{JOANNA HaŁACZKIEWICZ}

ELECTRONIC PUBLISHING OF THE COLLECTION OF LETTERS - ACHIEVEMENTS AND PERSPECTIVES

The article discusses the concept of scholarly edition of electronic correspondence and it also describes its most important features such as interactivity, nonlinearity, processuality. Next, technical aspects of creating electronic editions are examined, particularly the issue of coding in TEI-XML. The example is digital edition of letters and texts by Jan Dantyszek prepared by the team from the Department of Editing Sources and Digital Humanities of Warsaw University. Finally, the text presents the possibilities of developing scholarly e-editing of correspondence in the face of the foretold "death of a printing book".

KEY wORDs: scholarly digital edition, correspondence, digital humanities, textual criticism, TEI 